\title{
RELATIONSHIPS BETWEEN SUNFLOWER VARIETY, SOWING DATE AND THE EXTENT OF DAMAGE CAUSED BY THE EUROPEAN SUNFLOWER MOTH (Homoeosoma nebulellum Den. et Schiff.)
}

\author{
Szabó, B. ${ }^{*}$, Szabó, M. ${ }^{1}$, Varga, Cs. ${ }^{1}$, Tóth, F. ${ }^{2}$, Vagvölgyi, S. ${ }^{1}$ \\ ${ }^{1}$ College of Nyíregyháza, Department of Crop Science Nyíregyháza, \\ 4400 Stadion u. 31/b, Hungary \\ ${ }^{2}$ Szent István University, Faculty of Agricultural and Environmental Sciences, \\ Department Plant Protection, Gödöllö, Hungary
}

Received: June 01, 2009 Accepted: November 10, 2009

\section{SUMMARY}

Nyírség, in northeast Hungary, is one of the most important cultivation regions of confectionery sunflower used for toasting in Europe. The production area in this part of the country is over 20,000 ha. The importance of the crop keeps increasing due to its favorable nutritional properties. Apart from the hybrids suitable for husking produced on large scale, the cultivation area of the traditional open pollinated confectionery varieties is extending too. Kisvárda, an open pollinated variety, is the most widely produced. The abiotic and biotic stress resistance of this variety is excellent; however, it is susceptible to sunflower moth attack. The development of phytomelanin layer that would result in a decrease of susceptibility cannot be implemented without a change of the husk color, which in its turn is highly important on the market.

The experiments carried out between 2006 and 2008 had three objectives: first, it included a comparative study of two varieties belonging to the cultivar Kisvárda and two standard hybrids (one confectionary and one oil type) regarding their resistance to moth infestation; second, we wished to determine the effect of sowing time on the extent of moth contamination; and third, we searched for differences, if detectable, between the varieties with respect to the above mentioned aspects.

The experiments showed that it is the flowering time, determined by the growing period of the variety and the sowing time, that basically influences the extent of moth infestation.

Key words: sunflower moth, Homoeosoma, confectionary sunflower

* Corresponding author: Phone: +36-42 / 599-400 \#2601; Fax: +36-42 / 402-489;

e-mail: szabobe@nyf.hu 


\section{INTRODUCTION}

The stripe-patterned confectionary sunflower is still produced at small farms in Nyírség region. As the production of the variety Kisvárda demands manual labour, it is grown in fields of one to two hectares, or even smaller. The traditional manual technologies do not involve use of chemicals. Spraying with field machines - if needed - can be carried out only in first few months of the growing period because of the height of plants, while the small field size excludes aerial spraying (Szabó et al., 2008).

The sunflower moth seriously threatens confectionary sunflower. Husk damage in itself causes significant quality loss, and indirectly it allows the development of diseases resulting in head rot.

In addition to the varieties having phytomelanin layer, production of singleheaded varieties is recommended by Kadocsa (1947). According to his observations, these types, not having subsidary discs providing food for later generations, do not favour the reproduction of the moth.

The method most extensively applied against the pest is the development of varieties with a phytomelanin (carbon) layer into the husk, which mechanically prevents caterpillars from boring holes in the seed husk.

Based on the forms of the phytomelanin layer, five sensitivity groups of tandard hybrids have been distinguished by Horváth and Vecseri (2005).

Horváth also focused attention to the fact that the phytomelanin layer involves the resistance to Orobanche spp. as well. The thickness of the layer is in direct proportion with the resistance to the weed. Thus, examining the cross section of the husk under microscope allows to determine the reaction against the weed in different cultivars.

From the marketing point of view, the light husk color of the variety Kisvárda is an important factor. Accordingly, plant breeding should not be aimed at the development of the dark phytomelanin layer. Therefore, farming practices should begiven priority in the control of the pest.

Most of the damage is caused by second and third generations of the pest, whose most important host plant is the sunflower, especially the varieties whose lateral heads provide food continuously for later generations of the pest.

Horváth and Bujáki emphasized that the later a susceptible sunflower is sown, the higher is the intensity of moth infestation. This statement goes in favor of Kadocsa's observations that early sowing hinders the infestation.

The objective of this paper is to present the results of the experiments carried out from 2006 to 2008 within the framework of our long-term investigation. 


\section{MATERIAL AND METHODS}

Small-plot experiments were established in the locations of Geszteréd, Ajak and Nyíregyháza, important production areas of the confectionary sunflower. In Nyíregyháza, determination of the susceptibility for moth contamination by different varieties was carried out in a one-factorial, five-variety, four-replication experiment organized in the random block arrangement. In Geszteréd and Ajak, due to the properties and facilities of the areas, four replications could be sown in a single block. In these experiments, the open pollinated variety Kisvárda and one of its varieties with a short growing period, called Ajaki, two confectionary hybrids (Eagle and Marica) and an oil seed hybrid (Anita) were investigated.

In Geszteréd, the size of the experiment plot was 1.1 ha. The preceding crop was sunflower, while the neighboring area were under sunflower, forest and grassland. The soil texture was sandy loam, with the $\mathrm{pH}$ values in water and $\mathrm{KCl}$ of 5.29 and 4.23 , respectively.

In Ajak, confectionary sunflower is produced at more than 1000 ha. The size of the experimental field was 0.7 ha, with confectionary sunflower as the preceding crop. The soil texture was sand, with the $\mathrm{pH}$ values in water and $\mathrm{KCl}$ of 6.31 and 6.16 , respectively. The neighbouring crops were confectionary sunflower, oil seed sunflower and a sour cherry orchard.

During the growing period, plant protection measures were ot applied, except for hoeing.

In Nyíregyháza, the experiment was established in the Research Center of Debrecen University in 2006. The size of the experimental field was 2.95 ha, with the $\mathrm{pH}$ values in water and $\mathrm{KCl}$ of 6.29 and 5.31, respectively. The soil texture was sandy loam. The preceding crop was dry peas, while the neighbouring fields were sown to dry peas and oil seed sunflower, and there was also an orchards.

Before sowing, chemical weed control (Flubalex) and soil desinfection (Force $1.5 \mathrm{G}$ ) were carried out in the experiment fields. For pre-emergence weed control, Racer and Dual Gold 960 EC were applied. No further chemical treatment was used during the growing period.

In addition to the comparative study of the varieties, the effect of late sowing on moth infestation intensity in three sunflower varieties (Anita, Eagle and Kisvárda) was investigated in a two-factorial, four-replication experiment eatablished in a random block arrangement. Sowing was repeated at two-week intervals.

In Nyíregyháza, the 2006 experiments were repeated in 2007, the only difference being that the five varieties in the comparative experiment were sown within the framework of the sowing date experiment. The properties of the experimental plot were the same as in the preceding year. Ipiflour was applied in the field before sowing, while Racer and Dual Gold 960 EC after sowing.

In 2008, the sowing date experiment was repeated in Nyíregyháza. Four varieties (Eagle, Marica, Anita and Kisvárda) were investigated, in three different sowing 
dates. The soil texture was sand, the $\mathrm{pH}$ values in water and $\mathrm{KCl}$ were 6.63 and 5.28 , respectively. The preceding crop was faba bean, while the neighbouring crops were oil seed sunflower and dry peas. For weed control, Benefex was applied instead of Ipifluor.

For tracing the insect flight, transparent, sticky, triangle shaped CSALOMON traps were used (Plant Protection Institute, Hungarian Academy of Sciences, Budapest, Hungary). Two traps were placed per plot between 30 April and 5 May. Depending on plot size, the traps were located 50-200 $\mathrm{m}$ apart. The number of male moths was checked and registered on a weekly basis. The sticky plates and pheromone capsules were replaced as circumstances required. The last registration dates were 21-24 October in 2006 and 12 October in 2007 and 2008.

The extent of damage was surveyed three weeks after the swarming peak of the second generation. All heads at the experimental fields were examined, the numbers of infested and healthy heads registered, and the percentages of the former ones calculated. The statistical evaluation of the data was conducted according to Sváb (1981).

\section{RESULTS AND DISCUSSION}

\section{Comparative study of the varieties}

The 2006 swarming dynamics in the experimental plots is illustrated in Figure 1. The curves reveal great differences between the production fields. Of the three locations studied, the number of specimen was extremely high in Ajak (30-40 specimens/week). In Geszteréd and Nyíregyháza, the intensity of infestation was considerably lower (14-16 specimens/week). The swarming started earliest in Geszteréd, in the second half of May, followed by Ajak six weeks later, and finally Nyíregyháza. The swarming lasts until mid-October.

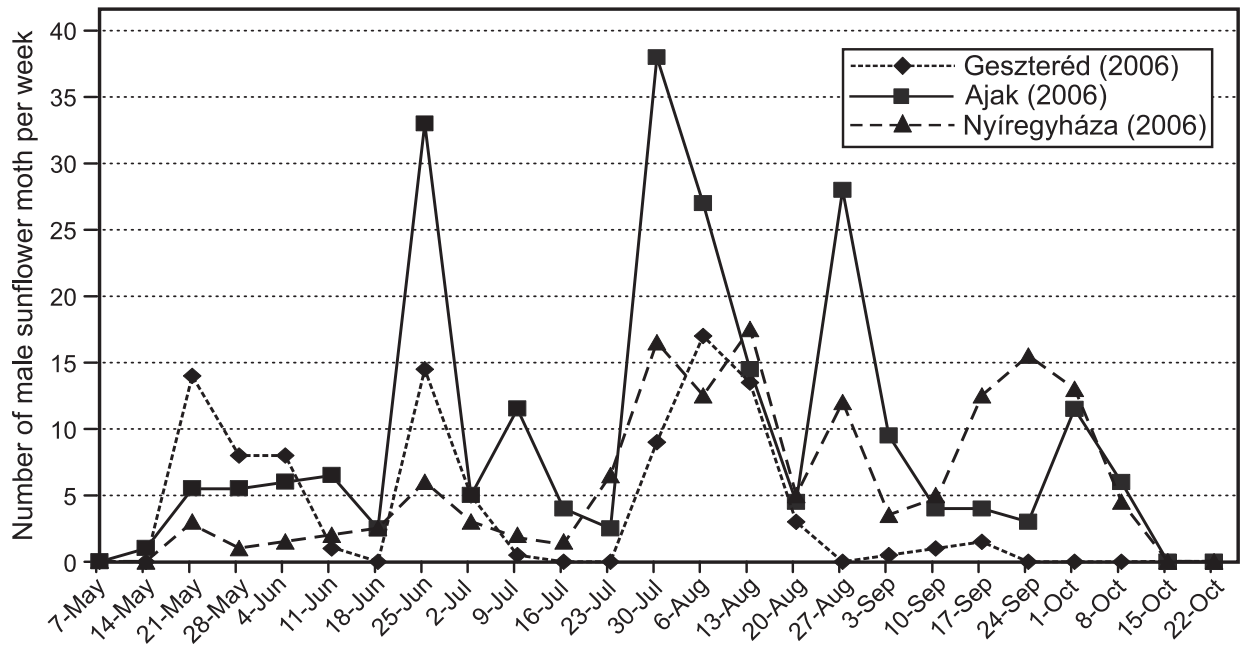

Figure 1: Seasonal flight pattern of sunflower moth in 2006 
Concerning moth infestation, significant differences were detectable in terms of the variety, production area, and their interaction (Figure 2). Taking into consideration all the varieties examined, the largest infestation intensity was observed in Geszteréd, 47.33\%, 22.33\% in Ajak, and 4.17\% in Nyíregyháza. The percentage of damage was considerably high in the case of the variety Anita, although it has the phytomelanin layer in the husk. However, the moth fed on its disk flowers and the head itself. There were some instances of husk damage, but these did not cause considerable yield loss. The variety Eagle, with a thick husk but no continuous phytomelanin layer, revealed a similar extent of damage with the husk chewed as a characteristic trait of damage. Having a thin husk and no phytomelanin layer, the varieties Marica and Ajak were the most heavily infested.

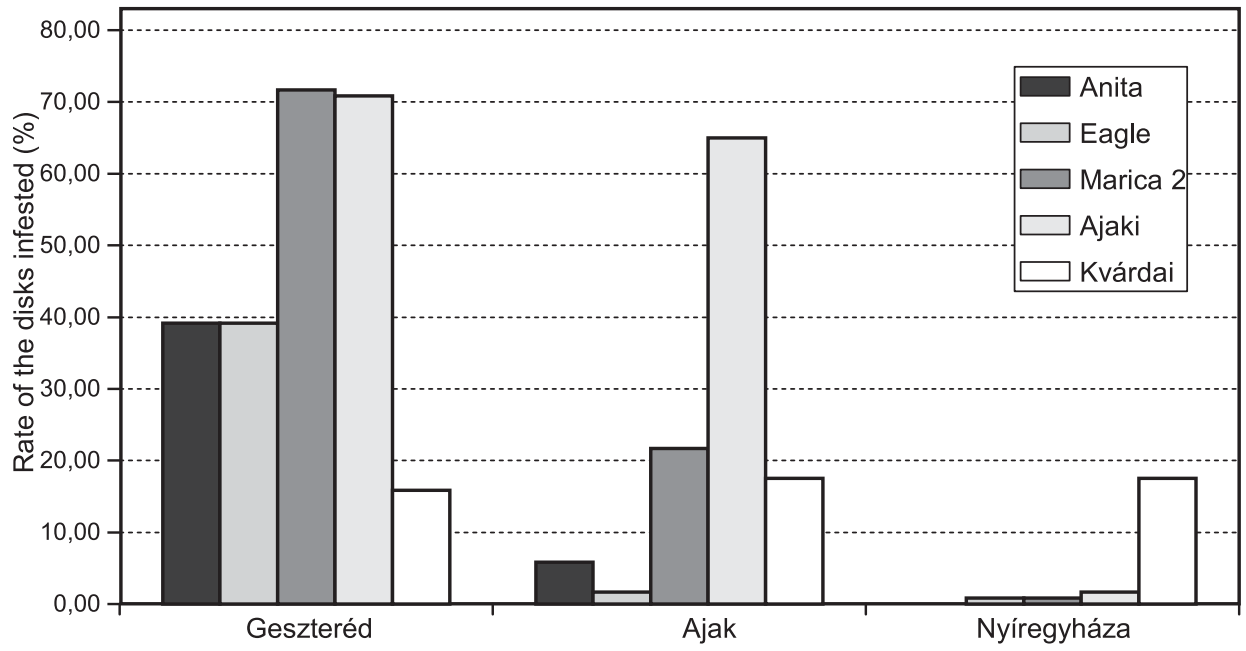

Fugure 2: Moth infestation of cultivars (2006)

Among the examined varieties, the variety Ajak showed the highest extent of contamination. The level of infestation observed in the variety Marica exceeded that of the variety Kisvárda, but the difference was not large. Low infestations were observed in the case of the cultivars Anita and Eagle. Near the experimental sites, Kisvárda varieties with different growing periods were produced at several small fields. So, regarding the moth swarming at the flowering time of the cultivar Kisvárda, a substantial quantity of host plants was at their disposal. At the flowering time of the cultivars Anita and Eagle, the culitvar Alexandra was also blooming in a neighboring field of 20 ha. The contamination of the cultivar Marica which flowered earlier can be explained by a relatively low number of host plants for the moth. This was not the case with the cultivar Ajak.

The lowest level of infestation in the case of the four early flowering varieties was observed in Nyíregyháza. The cultivar Kisvárda had the growing period 20-30 days longer than that of the other cultivars. A specific feature of this location was that several hundreds of genotypes were present at 3 ha, with many ornamental 
sunflowers among them, so that the moth could always find suitable host plants for oviposition. It means that the factors characterising isolated or less heterogeneous fields did not exist here.

As the sowing dates were close in the three locations (17 April in Ajak, 25 April in Geszteréd, and 26 April in Nyíregyháza), the considerable differences in the results can only be explained by special interactions characterizing each site. During the evaluation of the Geszteréd data, we had to take into consideration the fact that the experimental plots were scattered over an extensive grassland area with no neighbouring sunflower fields within several thousands of metres, except for the Kisvárda field of 1.1 ha. The variety Kisvárda revealed a homogeneous level of contamination.

Table 1: Average values of moth contamination of cultivars with different sowing dates (Nyíregyháza, 2006)

\begin{tabular}{lccc}
\hline Cultivar & \multicolumn{3}{c}{ Sowing date/contamination \% } \\
& 3 May & 23 May & 8 June \\
\hline Anita & 0.00 & 12.50 & 14.17 \\
Eagle & 1.26 & 10.83 & 15.00 \\
Kisvárdai & 17.50 & 25.00 & 28.34 \\
\hline
\end{tabular}

$\mathrm{SD}_{5 \%}=3.36$ between any two combinations

\section{Sowing date experiments}

As for the 2006 experiment with different sowing dates, the results were in accordance with those in the literature (Table 1). When sown early, the two early hybrids were either slightly damaged or not damaged at all. With the two other sowing dates, the intensity of infestation of the confectionary varieties grew with the passing of time. In the case of the oil seed hybrid as well, late sowing resulted in a higher level of infestation.

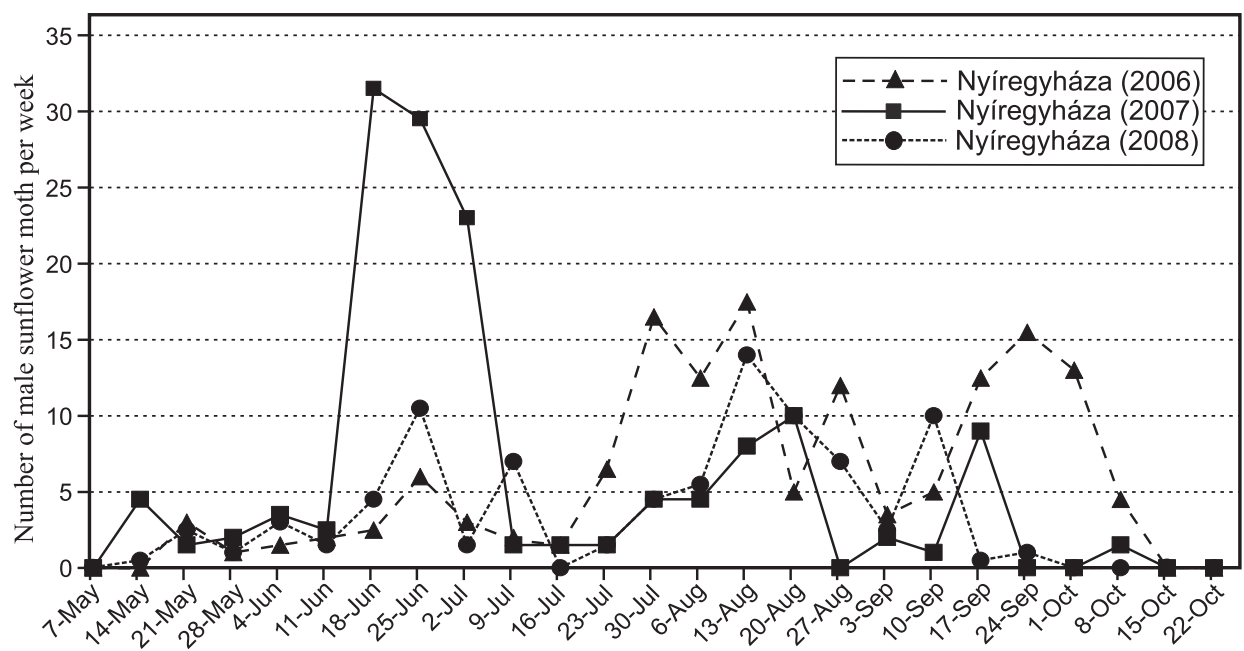

Figure 3: Seasonal flight pattern of sunflower moth in Nyíregyháza 
Regarding the varieties on an average, the intensity of infestation grew significantly between the first and the second sowing date. However, no significant difference was detected between the second and third dates. On average for the sowing dates, the variety Kisvárda was stood out while the two other examined varieties revealed no significant difference.

Table 2: Values of moth infestation of cultivars with different sowing dates (Nyíregyháza, 2007)

\begin{tabular}{lcccc}
\hline \multirow{2}{*}{ Cultivar } & \multicolumn{4}{c}{ Sowing date/contamination \% } \\
\cline { 2 - 5 } & 26 April & 11 May & 25 May & Average \\
\hline Anita & 0.42 & 0.00 & 6.25 & 2.22 \\
Eagle & 0.00 & 0.42 & 8.33 & 2.92 \\
Marica2 & 0.00 & 0.00 & 4.17 & 1.39 \\
Ajaki & 2.50 & 3.33 & 10.42 & 5.42 \\
Kisvárdai & 11.25 & 20.00 & 22.92 & 18.06 \\
Average & 2.83 & 4.75 & 10.42 & 6.00 \\
\hline $\mathrm{SD}_{5 \%}=3.49$ between any two combinations \\
\hline
\end{tabular}

In 2007, we started the sowing earlier. In spite of a different swarming dynamics (Figure 3), the dynamics of moth infestation was not different from the one observed in the previous year (Table 2). The experiment, similarly to that from 2006, revealed significant differences depending on sowing date. Unlike in 2006, however, a significant difference was observed in the interaction between the sowing dates and the varieties $(\mathrm{p}<0.001)$. The levels of contamination of the cultivars showed differences at later sowing dates. With the two earliest sowing dates, the two confectionary varieties and the oil seed hybrid practically remained uninfested. The cultivars Kisvárda and Ajak, belonging to the same type, were infested to a considerable extent at all the three sowing dates. The intensity of infestation of the cultivar Kisvárda, whose growing period was two weeks longer, was more than twice as high as the one in the cultivar Ajak at all sowing dates. As the husk properties of these two varieties are almost identical, the differences in the degree of infestation must be due to the different flowering times.

Table 3: Values of moth contamination of cultivars depending on sowing date (Nyíregyháza, 2008)

\begin{tabular}{lcccc}
\hline Cultivar & \multicolumn{4}{c}{ Sowing date/contamination \% } \\
\cline { 2 - 5 } & 15 April & 2 May & 21 May & Average \\
\hline Anita & 0.00 & 2.10 & 7.50 & 3.20 \\
Eagle & 0.00 & 2.50 & 7.53 & 3.34 \\
Marica2 & 0.00 & 2.10 & 9.15 & 3.75 \\
Kisvárdai & 6.68 & 27.93 & 33.35 & 22.65 \\
Average & 1.67 & 8.66 & 14.38 & 8.24 \\
\hline $\mathrm{SD}_{5 \%}=2.76$ between any two combinations \\
\hline
\end{tabular}

In the 2008 experiment, as indicated by the averages of the varieties, the intensity of moth infestation grew significantly as the sowing took place later and later (Table 3 ). This intensity was $1.67 \%$ in the first sowing, but as high as $14.38 \%$ in the 
third one. As for the different varieties, the average values of the three sowing dates revealed no difference between the varieties Eagle, Marica 2 and Anita in terms of moth infestation, while the variety Kisvárda was significantly more susceptible to the pest.

The data in the table show no significant difference between the infestation rates in the varieties Eagle, Marica 2 and Anita for the first and second sowing dates, but a difference existed between the second and the third date.

Although the cultivar Kisvárda was obviously more susceptible to moth attack, the extent of contamination grew with sowing date.

\section{CONCLUSIONS}

Based on the conducted experiments, we can state that the basic factor determining the level of sunflower moth infestation is the flowering time influenced by growing period of the variety and sowing date. As the sowing starts later and later, the number of days to flowering decreases, but it cannot compensate for the greater extent of moth contamination resulting from the later blooming. Thus, an early sowing is recommended for the variety Kisvárda, not only to increase the yield but also to decrease the rate of moth infestation.

\section{ACKNOWLEDGEMENTS}

We would like to thank Ms. Ildikó Huba for critical reading of the manuscript and the French version of the summary.

\section{REFERENCES}

Horváth, Z., 1996. Fontosabb hazai Orobanche fajok biológiája. Doktori értekezés tézisei, Keszthely-Bácsalmás.

Horváth, Z. és Bujáki, G., 1992. A Habrobracon hebetor Say (Hymenoptera: Braconidae) mint a napraforgómoly (Homoeosoma nebulellum $\mathrm{Hb}$.) legfontosabb hazai parazitája. Növényvédelem, 28: 196-200.

Horváth, Z és Vecseri, Cs., 2005. A napraforgómoly (Homoeosoma nebulellum Hb.) elleni biológiai és genetikai védekezési módszerek. 10. Tiszántúli Növényvédelmi Fórum. Debrecen 417-424.

Horváth, Z. és Fischl, G., 1996. A napraforgómoly (Homoeosoma nebulellum SCHIFF.) és a gyapottok-bagolylepke (Helicoverpa armigera Hb.) károsítása nyomán fellépö kórokozók napraforgó- és kukoricanövényeken. Növényvédelmi Fórum 96., Keszthely, Január 25-26: 17.

Kadocsa, Gy., 1947. A napraforgómoly és az ellene való védekezés. Fol. Ent. Hung. 2: 33-37

Klisiewitz, J.M., 1979. Relation of infection with sunflower moth Homoeosoma electellum larvae tothe incidience of Rhizopus head rot in sunflower seed heads. Can. J. Plant Sci., 59: 797-801.

Sárkány, S., 1947. A napraforgó nemesítése és a fitomelán kérdés Agrártud. Szemle. 1: $97-101$.

Seiler, G.J., Stafford, R.E. and Rogers, C.E., 1984. Prevalence of phytomelanin in pericarps of sunflower parental lines and wild species. Crop. Sci. 24: 1202-1204.

Sváb, J., 1981. Biometriai módszerek a kutatásban, Mezögazdasági Kiadó, Budapest. pp. 557.

Szabó, B., Tóth, F. és Vágvölgyi, S., 2008. A napraforgómoly (Homoeosoma nebulellum Den. et Schiff.) rajzásdinamikájának és a kártételének vizsgálata a Nyírségben. Növényvédelem 44(1): 34-38. 


\title{
EL EFECTO DE LA VARIEDAD Y EL TIEMPO DE SIEMBRA EN LOS PERJUICIOS OCASIONADOS POR LA POLILLA DEL GIRASOL (Homoeosoma nebulellum Den. et Schiff.)
}

\author{
RESUMEN
}

La región de Nyírség localizada en el vértice noreste de Hungría, es la zona mas importante entre las dedicadas a la producción de girasol para tostar. Los terrenos cultivados en la región alcanzan las 20.000 hectareas. La importancia de la producción de girasol va en aumento gracias a que sus propiedades fisio-alimentarias se hacen cada vez mas evidentes. Fuera de las variedades híbridas utilizadas para descascarar producidas con métodos de gran explotación, los campos cultivados con variedades de tradicional desfloración libre son cada vez mayores. Entre las de este último grupo la variedad que se cultiva en mayor cantidad es la de Kisvárda cuya resistencia al estres abiótica y biótica desde un punto de vista agrotécnico se puede considerar de muy buena. Sin embargo a los perjuicios de la polilla del girasol es poco resistente. La disminución de este echo a partir de la introducción de una capa de fitomelania no es posible sin la modificación del color de la cáscara que significa su valor de mercado. Los objetivos de los experimentos realizados entre 2006 y 2008 fueron los de realizar una comparación de la resistencia contra la polilla del girasol de dos variantes de la variedad Kisvárda y de dos variedades híbridas relativamente propagadas en el país para consumo directo y para fabricación de aceite. Por otra parte tambien fué objetivo examinar en que valor condiciona el tiempo de siembra el grado de infección por polilla y si hay diferencia entre variedades.

Con base a los experimentos se puede determinar si la fecha de floración es un factor condicionante básico del grado de infección por polilla, lo cual es determinado por el tiempo siembra y el tiempo de vida vegetativo.

\section{LES INFLUENCES DE LA VARIANTE ET DE L'HEURE D'ENSEMENCEMENT SUR LES DÉGÂTS DE LA PYRALE DU TOURNESOL (Homeosoma nebulellum Den. et Schiff.)}

\author{
RÉSUMÉ
}

La Nyírség, qui se situe au nord-est de la Hongrie, est une des régions les plus importantes en Europe quant à la production du tournesol alimentaire à griller. Ici, la surface ensemencée surmonte 20000 ha. L'importance du tournesol alimentaire est en constante augmentation. Cependant, parmi les variantes à griller, celle de Kisvárda, qui est produite dans le plus grand territoire, est susceptible des dégâts de la pyrale du tournesol. Le but des expériences faites en 2006-2008 était de conférer les susceptibilités de pyrale de deux variantes de Kisvárda, deux hybrides alimentaires et un hybride oléique. Nous avons examiné la mesure dans laquelle l'heure d'ensemencement influait sur la contamination et s'il y avait quelque différence parmi les variantes de ce point de vue. En vertu des expériences, nous pouvons constater que c'est l'heure de floraison, déterminée par le temps de végétation et l'heure d'ensemencement, qui influence la mesure de la contamination de façon décisive. 
